\title{
Gambaran Foto Toraks Tuberkulosis Paru Genotipe Beijing dan Non-Beijing
}

\author{
Ristaniah D. Soetikno, ${ }^{1}$ Ida Parwati ${ }^{2}$ \\ Bagian Radiologi, ${ }^{1}$ Bagian Patologi Klinik ${ }^{2}$ \\ Fakultas Kedokteran Universitas Padjadjaran \\ Rumah Sakit Hasan Sadikin, Bandung
}

\begin{abstract}
Abstrak
Mycobacterium tuberculosis genotipe Beijing mempunyai virulensi lebih tinggi, tersebar global, dan lebih resisten dibanding non-Beijing. Penelitian analitik observasional dengan rancangan potong silang untuk mengetahui gambaran foto toraks pada kedua genotipe dilakukan periode September 2003-Desember 2005 di Rumah Sakit Hasan Sadikin Bandung. Pembacaan foto toraks oleh dua ahli radiologi. Subjek terdiri dari 206 laki-laki dan 196 perempuan, 131 genotipe Beijing dan 271 non-Beijing. Usia rata-rata 31 tahun. Hasil pembacaan oleh pengamat I pada genotipe Beijing menunjukkan gambaran ringan 60 (45,8\%) dan berat 71 (54,2\%); genotipe non-Beijing gambaran ringan $205(75,6 \%)$ dan berat 66 (24,4\%). Pengamat II untuk genotipe Beijing 62 (47,3\%) dan 69 (52,7\%); genotipe non-Beijing $208(76,8 \%)$ dan 63 (23,2\%). Diperoleh perbedaan bermakna antara genotipe Beijing dan non-Beijing $(\mathrm{p}<0,05)$. Kavitasi genotipe Beijing 69 (52,7\%) baik pengamat I maupun II, sedangkan non-Beijing berturut-turut $61(22,5 \%)$ dan 60 (22,1\%), dengan p<0,05. Kavitas $\geq 4 \mathrm{~cm}$ pada genotipe Beijing $42(60,0 \%)$ oleh pengamat I dan $40(58,0 \%)$ oleh pengamat II, tidak terdapat perbedaan bermakna kavitas $<4$ dengan $\geq 4 \mathrm{~cm}(\mathrm{p}>0,05)$. Kesesuaian foto toraks pengamat I dengan II untuk gambaran ringan 265 dari 270 dan berat 132 dari 137 ( $\dot{\mathrm{K}}>0,80$ ). Disimpulkan gambaran foto toraks genotipe Beijing lebih berat dan lebih banyak kavitasi. [MKB. 2010;42(3):92-5].
\end{abstract}

Kata kunci: Foto toraks, genotipe Beijing, genotipe non-Beijing, tuberkulosis paru

\section{Thoracic Photo Profile of Lung Tuberculosis Beijing and Non Beijing Genotypes}

\begin{abstract}
Beijing genotype Mycobacterium tuberculosis has higher virulence, spread globally, and more resistant compare with non Beijing. Observational analytic study with cross sectional design to determine the thoracic photos profile of the two genotypes, was done September 2003-December 2005 at Hasan Sadikin Hospital Bandung. Thoracic photos were analyzed by two radiologists. Subjects consisted of 206 men and 196 women comprising of 131 Beijing and 271 non Beijing. The mean age was 31 years. Thoracic photo description by observer I on Beijing showed 60 (45.8\%) mild and 71 (54.2\%) severe; non Beijing 205 (75.6\%) mild and 66 (24.4\%) severe. Observer II were 62 (47.3\%) mild and 69 (52.7\%) severe of Beijing; 208 (76.8\%) and 63 (23.2\%) non Beijing, respectively. There was significant difference between Beijing and non Beijing $(\mathrm{p}<0.05)$. Cavitation of Beijing by both observer was 69 $(52.7 \%)$, whereas non Beijing were $61(22.5 \%)$ and $60(22.1 \%)$, respectively $(\mathrm{p}<0.05)$. Cavitation of Beijing $\geq 4 \mathrm{~cm}$ was $42(60.0 \%)$ by observer I and $40(58.0 \%)$ by observer II, there was no significant difference between $<4$ and $\geq 4$ $\mathrm{cm}(\mathrm{p}>0.05)$. Similarity description from two radiologist was 265 of 270 in mild, and 132 of 137 in severe $(\kappa>0.80)$. In conclusion, thoracic photos of Beijing genotype is significantly more severe with more cavitation.
\end{abstract}

[MKB. 2010;42(3):92-5].

Key words: Beijing genotype, lung tuberculosis, non Beijing genotype, thoracic photo

Korespondensi: Dr. dr. Ristaniah D. Soetikno, Sp.Rad(K)., M.Kes., Bagian Radiologi, Fakultas Kedokteran Universitas Padjadjaran, Rumah Sakit Hasan Sadikin, jalan Pasteur 38 Bandung 40161, telepon (022) 2034915, mobile 087822081117 , e-mail: ristasoetikno@gmail.com 


\section{Pendahuluan}

Tuberkulosis (TB) paru sampai saat ini masih merupakan suatu masalah kesehatan dunia karena angka kesakitan dan kematian cukup tinggi, serta penyebab kematian kedua terbanyak akibat penyakit infeksi. ${ }^{1}$ Indonesia merupakan negara ketiga terbanyak yang terjangkit TB setelah India dan Cina. ${ }^{2}$ Peningkatan global TB saat ini lebih tinggi dibandingkan dengan beberapa dekade yang lalu, antara lain disebabkan oleh munculnya strain baru Mycobacterium tuberculosis (M. tb) yang sifatnya multi drug resistant tuberculosis (MDR-TB) sehingga menimbulkan permasalahan baru. ${ }^{2,3}$ Teknik baru seperti finger printing deoxyribonucleic acid (DNA) dapat mendeteksi keragaman genetik $M$. tb, di antaranya genotipe Beijing dan non-Beijing sehingga perkembangan epidemiologi molekular TB meningkat. Teknik spaceroligonucleotide typing (spoligo typing) merupakan teknik yang tersering digunakan. ${ }^{4}$ Genotipe Beijing merupakan penyebab terbanyak $(87,5 \%)$ kasus MDR-TB di Estonia dengan angka resistensi yang paling tinggi di dunia, ${ }^{6,7}$ cepat menyesuaikan diri terhadap lingkungan, tersebar global, dan lebih virulen dibandingkan dengan genotipe lainnya. ${ }^{8,9}$ Prevalensi tertinggi genotipe Beijing di Asia Tenggara ditemukan di negara Vietnam (50,6\%), Thailand (48\%), dan Indonesia $(35,2 \%){ }^{8}$

Foto toraks merupakan penunjang diagnosis penting karena dapat membantu menegakkan diagnosis TB paru. Pemeriksaan ini mempunyai keuntungan dibandingkan dengan pemeriksaan sputum mikroskopis tiga kali yang identik dengan pemeriksaan biakan sebagai baku emas untuk diagnosis TB paru karena lebih mudah dan cepat dilakukan. $^{10}$

Tujuan penelitian adalah untuk mengetahui perbedaan gambaran abnormalitas foto toraks penderita TB paru yang disebabkan oleh $\mathrm{M}$. tb genotipe Beijing dengan non-Beijing.

\section{Metode}

Sebanyak 402 subjek penelitian yang terdiri dari penderita TB paru yang terinfeksi M. tb genotipe Beijing sebanyak 131 dan non-Beijing sebanyak 271. Genotipe Beijing dan non-Beijing ditentukan dengan finger printing DNA (spoligo typing). Bahan pemeriksaan spoligo typing berasal dari sputum penderita TB paru. Terisinya spacer 35 sampai 43 secara berurutan merupakan tanda $\mathrm{M}$. tb genotipe Beijing.

Subjek penelitian terdiri dari 206 laki-laki dan 196 perempuan. Rata-rata usia subjek penelitian adalah 31 tahun (15-66 tahun). Pemilihan subjek penelitian dilakukan berdasarkan urutan datang penderita, sejak September 2003 sampai dengan Desember 2005.

Pemeriksaan foto toraks dilakukan untuk menilai luas lesi dan konsolidasi homogen, serta kavitasi. Gambaran foto toraks yang dibaca oleh dua orang ahli radiologi diinterpretasikan sebagai gambaran ringan dan berat.

Penelitian ini merupakan penelitian analitik observasional dengan rancangan potong silang, bekerja sama dengan Immunogenetic TB-Beijing Study di bawah pengawasan Poverty Related Infection Oriented Research (PRIOR) Fakultas Kedokteran Universitas Padjadjaran Bandung.

Analisis data berdasarkan uji kai-kuadrat $\left(\mathrm{x}^{2}\right)$ dengan perhitungan tabel $2 \times 2$. Apabila diperoleh hasil $\mathrm{p}<0,05$ maka dianggap bermakna. Hasil pembacaan foto toraks yang dilakukan oleh dua orang ahli radiologi dianalisis menggunakan uji Kappa (koefisien kesesuaian). Bila diperoleh hasil $>0,80$ maka dianggap sangat baik, antara $0,60-0,80$ maka dianggap memadai, serta $<0,60$ kurang baik. Seluruh perhitungan statistika dikerjakan dengan menggunakan piranti lunak SPSS versi 13.0.

\section{Hasil}

Dari 402 subjek penelitian yang masuk kriteria inklusi, didapat usia rata-rata 31 tahun (15-66 tahun) dengan distribusi penderita TB paru yang terbanyak kelompok usia 20-29 tahun. Subjek penelitian laki-laki sedikit lebih banyak dibanding perempuan yaitu 1:1,05.

Hasil foto toraks kelompok genotipe Beijing dengan gambaran berat lebih banyak dibanding ringan. Gambaran berat pada kelompok Beijing lebih banyak dibandingkan dengan non-Beijing. Secara statistik terdapat perbedaan bermakna $(\mathrm{p}<0,05)$ antara beratnya gambaran foto toraks kelompok Beijing dan non-Beijing (Tabel 1). Pengamat I menemukan kavitasi sebanyak 69 $(52,7 \%)$ pada kelompok Beijing dan $61(22,5 \%)$ pada non-Beijing, sedangkan pengamat II mendapatkan $69(52,7 \%)$ pada kelompok Beijing 
Tabel 1 Gambaran Radiologi

\begin{tabular}{|c|c|c|c|c|c|c|c|}
\hline \multirow{3}{*}{$\begin{array}{l}\text { Gambaran } \\
\text { Radiologi }\end{array}$} & \multicolumn{4}{|c|}{ Genotipe } & \multirow{2}{*}{\multicolumn{2}{|c|}{ Total }} & \multirow{3}{*}{ Kemaknaan } \\
\hline & \multicolumn{2}{|c|}{ Beijing } & \multicolumn{2}{|c|}{ Non-Beijing } & & & \\
\hline & Jumlah & $\%$ & Jumlah & $\%$ & Jumlah & $\%$ & \\
\hline \multicolumn{8}{|l|}{ Pengamat I } \\
\hline Ringan & 60 & 45,8 & 205 & 75,6 & 265 & 65,9 & \multirow{3}{*}{$\begin{array}{c}x^{2}=35,012 \\
p=0,000\end{array}$} \\
\hline Berat & 71 & 54,2 & 66 & 24,4 & 137 & 34,1 & \\
\hline Total & 131 & 100 & 271 & 100 & 402 & 100 & \\
\hline \multicolumn{8}{|l|}{ Pengamat II } \\
\hline Ringan & 62 & 47,3 & 208 & 76,8 & 270 & 67,2 & \multirow{3}{*}{$\begin{array}{c}x^{2}=34,670 \\
p=0,000\end{array}$} \\
\hline Berat & 69 & 52,7 & 63 & 23,2 & 132 & 32,8 & \\
\hline Total & 131 & 100 & 271 & 100 & 402 & 100 & \\
\hline
\end{tabular}

Tabel 2 Gambaran Kavitasi

\begin{tabular}{|c|c|c|c|c|c|c|c|}
\hline \multirow{3}{*}{ Kavitasi } & \multicolumn{4}{|c|}{ Genotipe } & \multirow{2}{*}{\multicolumn{2}{|c|}{ Total }} & \multirow{3}{*}{ Kemaknaan } \\
\hline & \multicolumn{2}{|c|}{ Beijing } & \multicolumn{2}{|c|}{ Non-Beijing } & & & \\
\hline & Jumlah & $\%$ & Jumlah & $\%$ & Jumlah & $\%$ & \\
\hline Pegamat I & & & & & & & \multirow{4}{*}{$\begin{array}{c}\mathrm{x}^{2}=36,719 \\
\mathrm{p}=0,000\end{array}$} \\
\hline Negatif & 62 & 47,3 & 210 & 77,5 & 272 & 67,7 & \\
\hline Positif & 69 & 52,7 & 61 & 22,5 & 130 & 32,3 & \\
\hline Total & 131 & 100 & 271 & 100 & 402 & 100 & \\
\hline \multicolumn{8}{|l|}{ Pengamat II } \\
\hline Negatif & 62 & 47,3 & 211 & 77,9 & 273 & 67,9 & \multirow{3}{*}{$\begin{array}{c}x^{2}=37,776 \\
p=0,000\end{array}$} \\
\hline Positif & 69 & 52,7 & 60 & 22,1 & 129 & 32,1 & \\
\hline Total & 131 & 100 & 271 & 100 & 402 & 100 & \\
\hline
\end{tabular}

Tabel 3 Ukuran Kavitas

\begin{tabular}{|c|c|c|c|c|c|c|c|}
\hline \multirow{3}{*}{$\begin{array}{l}\text { Ukuran } \\
\text { kavitas }\end{array}$} & \multicolumn{4}{|c|}{ Genotipe } & \multirow{2}{*}{\multicolumn{2}{|c|}{ Total }} & \multirow{3}{*}{ Kemaknaan } \\
\hline & \multicolumn{2}{|c|}{$\begin{array}{l}\text { Beijing } \\
\end{array}$} & \multicolumn{2}{|c|}{ Non-Beijing } & & & \\
\hline & Jumlah & $\%$ & Jumlah & $\%$ & Jumlah & $\%$ & \\
\hline Pengamat I & & & & & & & \multirow{4}{*}{$\begin{array}{c}x^{2}=2,604 \\
p=0,107\end{array}$} \\
\hline$<4 \mathrm{~cm}$ & 27 & 40,0 & 33 & 54,1 & 60 & 46,6 & \\
\hline$\geq 4 \mathrm{~cm}$ & 42 & 60,0 & 28 & 45,9 & 70 & 53,4 & \\
\hline Total & 69 & 100 & 61 & 100 & 130 & 100 & \\
\hline \multicolumn{8}{|l|}{ Pengamat II } \\
\hline$<4 \mathrm{~cm}$ & 29 & 42,0 & 30 & 50,0 & 59 & 45,7 & \multirow{3}{*}{$\begin{array}{c}x^{2}=0,822 \\
p=0,365\end{array}$} \\
\hline$\geq 4 \mathrm{~cm}$ & 40 & 58,0 & 30 & 50,0 & 70 & 54,3 & \\
\hline Total & 69 & 100 & 60 & 100 & 129 & 100 & \\
\hline
\end{tabular}

dan $60(22,1 \%)$ pada non-Beijing (Tabel 2). Hal ini menunjukkan bahwa kavitasi pada foto toraks secara bermakna lebih banyak pada genotipe Beijing dibanding non-Beijing. Ukuran kavitas $\geq 4$ cm pada kelompok genotipe Beijing ditemukan 42 $(60,0 \%)$ oleh pengamat I dan $40(58,0 \%)$ oleh pengamat II (Tabel 3), tetapi secara statistik tidak terdapat perbedaan bermakna $(\mathrm{p}>0,05)$ antara kavitas $<4$ dan $\geq 4 \mathrm{~cm}$, baik pada pengamat I maupun pegamat II. Kesesuaian foto toraks antara pengamat I dan II untuk gambaran ringan adalah sebanyak 265 dari $270(98,15 \%)$ dan untuk gambaran berat adalah sebanyak 132 dari 137 $(96,35 \%)$, dengan $\dot{\kappa}=0,927$.

\section{Pembahasan}

Kasus TB paru genotipe Beijing paling banyak didapat pada kelompok usia 20-29 tahun (46,6\%). Hal tersebut sesuai dengan penelitian Anh et al. ${ }^{11}$ di Vietnam bahwa $54 \%$ penderita $M$. tb genotipe Beijing berkorelasi dengan usia yang lebih muda, sedangkan penelitian di Indonesia sebelumnya terdapat 42,4\% kasus TB paru genotipe Beijing pada usia 30-49 tahun. $^{8}$ Proporsi jenis kelamin pada kelompok TB paru genotipe Beijing dengan non-Beijing terdapat sedikit perbedaan, begitu juga pada masing-masing genotipe. Hal ini sesuai dengan Glynn et $a{ }^{8}{ }^{8}$ yang menyatakan tidak ada 
perbedaan jenis kelamin infeksi M. tb antara genotipe Beijing dan non-Beijing.

Gambaran berat pada foto toraks kelompok genotipe Beijing lebih banyak dibandingkan dengan ringan, sedangkan pada kelompok genotipe non-Beijing, gambaran ringan lebih banyak dibanding berat. Secara statistik terdapat perbedaan bermakna $(p<0,05)$ gambaran foto toraks antara kelompok genotipe Beijing dan nonBeijing. Hasil penelitian ini sesuai dengan penelitian Drobniewski et al. ${ }^{12}$ bahwa kelompok genotipe Beijing berhubungan dengan beratnya gambaran foto toraks, yaitu adanya gambaran fibrokavernosa yang secara bermakna lebih banyak ditemukan dibanding non-Beijing. Hasil foto toraks kelompok genotipe Beijing dengan gambaran kavitas lebih banyak dibandingkan dengan gambaran tidak terdapat kavitas, sedangkan pada non-Beijing sebaliknya. Hasil perhitungan statistik kedua pengamat untuk perbandingan kavitasi pada kelompok genotipe Beijing dan non-Beijing menunjukkan perbedaan bermakna $(p<0,05)$. Kavitas dengan ukuran $\geq 4 \mathrm{~cm}$ pada kelompok genotipe Beijing lebih banyak dibanding non-Beijing, sedangkan kavitas dengan ukuran $<4 \mathrm{~cm}$ lebih banyak ditemukan pada nonBeijing, tetapi tidak menunjukkan perbedaan bermakna $(\mathrm{p}>0,05)$.

Hasil interpretasi gambaran abnormalitas foto toraks yang dibaca oleh pengamat I dan pengamat II, baik dalam penilaian luas lesi dan konsolidasi, gambaran kavitas, serta penilaian ukuran kavitas, tidak jauh berbeda. Kesesuaian pembacaan foto toraks oleh dua orang ahli radiologi diperoleh nilai Kappa yang sangat baik $(\kappa>0,80)$, artinya nilai kesesuaian antara pengamat I dan II dalam pembacaan foto toraks ini sangat tinggi.

Kesimpulan dari penelitian ini adalah bahwa gambaran foto toraks pada penderita TB yang terinfeksi M. tb genotipe Beijing lebih berat dibandingkan dengan non-Beijing. Kavitasi lebih banyak ditemukan secara bermakna pada foto toraks penderita TB genotipe Beijing.

Penelitian lebih lanjut perlu dilakukan untuk mengetahui hubungan gambaran foto toraks dengan tingginya angka kejadian kasus relaps TB dan kegagalan penatalaksanaan anti-TB pada pasien TB paru terinfeksi M. tb genotipe Beijing.

\section{Daftar Pustaka}

1. Frieden RT, Sterling TR, Munsiff SS, Watt CJ, Dye C. Tuberculosis. Lancet. 2003;362:887-99.

2. Departemen Kesehatan RI. Pedoman nasional penanggulangan tuberkulosis. Jakarta: Depkes RI; 2005.

3. World Health Organization. Laboratory services in tuberculosis control. Bagian 11: Microscopy. Geneva: WHO; 1998.

4. Von Soolingen D, Herman PWM, de Haas PEW, Soll DR, van Embden JDA. Occurance and stability of insertion sequences in complex sterm : Evaluation of an insertion sequence dependent DNA polymorphisms a tool in the epidemiology of tuberculosis. J Clin Microbiol. 1991;29:257886.

5. Van der Zanden AGM, Hontjen AH, Heilmann FGC, Weltevreden EF, Schouls LM, van Embden JDA. Simultaneous detection and strain differentiation of Mycobacterium tuberculosis complex in paraffin embedded tissue and in stamded microscopic preparation. J Clin Pathol. 1998;51:209-14.

6. Anti tuberculosis drug resistant in the world, report no. 2: prevalence and trend. The WHO/IUATLD Global Project on Anti Tuberculosis Resistant Surveillance. Geneva: CDC-WHO; 2000.

7. Krunner A, Hoffner SE, Sillastu H, Danilovits N, Levina K, Svenson SB, et al. Spread of drug resistant pulmonary tuberculosis in Estonia. J Clin Microbiol, 2001;39:3339-45.

8. Glynn JR, Whiteley J, Bifani PJ, Kremer K, van Soolinger D. Worldwide occurrence of Beijing-W strain of Mycobacterium tuberculosis: a systhematic review. Emerg Infect Dis. 2002;8: 843-9.

9. Lopez B, Aquilar D, Orosco H, Burger M, Espitia $\mathrm{C}$, Ritacco $\mathrm{V}$, et al. A marked difference in pathogenesis and immune response induced by different M. tuberculosis Beijing genotype. Clin Exp Immunol. 2003;133(1):20-1.

10. Aditama TY. Tuberkulosis: diagnosis, terapi, dan masalahnya. Edisi ke-4. Jakarta: Yayasan Penerbitan Ikatan Dokter Indonesia; 2002.

11. Anh DD, Borgdoff MW, Lan NTN, Gorkim TV, Kremer K. Beijing genotype emerging in Vietnam. Emerg Infect Dis. 2000;6:302-5.

12. Drobniewski F, Balabanova Y, Nikolayevsky V, Ruddy M, Kuznetzov S, Zakharova S, et al. Drugresistant tuberculosis, clinical virulence, and the dominance of the Beijing strain family in Russia. JAMA. 2005;293(22):2726-31. 